\title{
CURSORY VIEWPOINT ON TRANSNISTRIA AS THE FOCUS OF THE RUSSIAN FEDERATION POLICY
}

\section{INTRODUCTION}

The Pridnestrovian Moldavian Republic (PMR), also known as Transnistria, emerged as de facto state in result of an armed conflict which took place in March-July 1992 on the territory of Moldova. According to the international law Transnistria is a part of the Republic of Moldova, but for many years this breakaway territory develops separately from its parent state. Transnistria started its independent policy because of several reasons. Among them language policy in Moldova at the end of 1980s and at the beginning of 1990s, Moldova's aspirations to unite with Romania, interests of political and business leaders of Transnistria wishing to preserve close ties with the Russian Federation. The separation of Transnistria occurred at a time of the USSR collapse after which Russia as a successor of the USSR attempted to preserve its influence on the post-Soviet space in general and in Transnistria in particular.

Transnistria is relatively small in territory and population, but during the Soviet era it had a great industrial potential which was 37 percent of the industrial capacity of the Moldavian SSR (Vardanean, 2018: 34). Nowadays it is quite poor territory relying to some extent on Russian assistance. Since the Russian Federation interferes in many spheres of life of Transnistria, complex research concerning its activity in this unrecognized republic is needed. It is also important to discuss how this activity influences on Transnistria, and what benefits Russia gets by its presence there. The purpose of this article is to outline cursory viewpoint on activity of the Russian Federation in Transnistria from the time of emergence of this de facto state till now.

Russian interference in Moldova's affairs was a subject of research of many scholars, but there is no unanimity among them concerning the evaluation of the Russian impact on Transnistria. Ruslan Kermach characterizes Russia "as a long-term contributor and de facto patron of the Transnistrian breakaway republic of Moldova over the whole period of its existence" (Kermach, 2017: 15). Thomas de Waal evaluates the Russian policy concerning Transnistria as more flexible than concerning other de facto states, such as Abkhazia for example. It is connected with the fact that Russia often balanced between support of the government in Tiraspol and close ties with Moldova (De Waal, 2018: 35-39). Adrian Rogstad considers that in the focus of Russia's inter- 
est is not Transnistria as such, but maintaining as much influence as possible over the whole Moldova (Rogstad, 2016: 18). A similar view is held by Pål Kolstø and Andrei Malgin regarding that as Russia was interested in Moldova's active membership in the Commonwealth of Independent States partnership, it forced Transnistria to extend concessions to Chisinau. Moreover, Moscow's attitude to Transnistria often changed due to the "balance of forces in Russian politics" (Kolstø, Malgin, 1998: 121). John Beyer and Stefan Wolff consider that Russia's interest in Transnistria is connected with geopolitical reasons as its influence is a "part of a greater geopolitical game in the shared neighborhood" (Beyer, Wolff, 2016: 344). According to Paul Quinlan, for the Russian President Vladimir Putin Transnistria "is a pawn in Russia's zero-sum game with the West over ultimate control of the "near abroad" (Quinlan, 2020: 392). Ana Jović-Lazić and Jovanka Kuvekalović-Stamatović regard that Transnistria is very important for Russia because of its strategic and economic value to the Black Sea region in terms of historical retrospect (Jović-Lazić, Kuvekalović-Stamatović, 2020: 34).

For the Russian Federation Transnistria is an instrument to reach as much benefits as possible in the South-East Europe. Uncertain situation concerning the status of Transnistria on the international arena plays into the hands of the Kremlin as it can influence on this de facto state by providing support which is very much needed for this unrecognized republic from one side, and manipulate Moldova from the other. Russia undoubtedly plays a significant role in the life of Transnistria, but it should be highlighted that its activity in different spheres has its own trajectory and intensity. Moreover, notwithstanding Transnistria is an active perceiver of Russian assistance, it simultaneously cooperates with the Republic of Moldova and Western countries (Popescu, Litra, 2012: 1).

The Transnistrian de facto state borders Ukraine on the northeast and Moldova on the southwest. Russian presence in Transnistria is aimed at influence on the Ukrainian policy, especially after the Russian annexation of Crimea and aggression in Eastern Ukraine. From the point of view of Mykola Doroshko, the unresolved status of the conflict in Transnistria gives the Kremlin an opportunity to push not only on Moldova but also on Ukraine (Doroshko, 2012: 56). By its policy Russia tries to surround Ukraine from different directions and predetermine its geopolitical vector of development.

Thus, providing influence on Transnistria Russia involves this de facto state in a zone of its geopolitical interest, provides better control over Moldova, receives additional instruments to push on Ukraine, and widens its sphere of political, economic and cultural influence. The intentions of the Russian Federation have a long-term character connected with its geostrategic ambitions on the former Soviet space.

\section{MILITARY PRESENCE OF THE RUSSIAN FEDERATION ON THE TERRITORY OF TRANSNISTRIA}

Military cooperation is very important for Moscow and Tiraspol. The $14^{\text {th }}$ Army of the USSR has been deployed on the territory of Transnistria since the Soviet times. During the violent conflict in 1992 Transnistria was supported by it as the Russian Federation considered the territory of Transnistria its Southern outpost. Personnel of 
the $14^{\text {th }}$ Army was interested in a long-term presence in this de facto state. It was connected with the fact that $80 \%$ of its contingents were locals whose families lived in Transnistria. The authorities of Transnistria were ready to preserve all privileges of the Russian military personnel there (Kolosov, 2007: 42). The authors regard that Russian army was perceived by the population of Transnistria as a specific way to continuation of the Soviet era and a guarantor of inviolability of the territory of this unrecognized republic. Tiraspol was interested in its deployment there and considered it not only from military, but also from political point of view.

After the end of an active phase of the conflict the Russian military retained its presence in Transnistria. It can be seen as a clear demonstration of Russian "near abroad" policy provoked by Russia's fear that Moldova could drift from its political and cultural sphere of influence (Buttin, 2007: 15). In April 1995 the General Staff of the Armed Forces of the Russian Federation changed the name of the $14^{\text {th }}$ Army to the Operational Group of the Russian Forces in the Transnistrian Region of the Republic of Moldova. From the early 1990s till now the Russian troops decreased from 10,000 to 1,400 . An amount of Russian ammunition situated in the village of Kolbasna in Rybnitsa region was reduced by half and now about 20,000 tons of it are located there (De Waal, 2018: 39; Moldova v OBSIe, 2019).

Russian army and ammunition had to be withdrawn from the region according to several documents. In 1994 Russia and Moldova signed an agreement which obliged the Russian Federation to withdraw its troops in three years, but the Russian Duma had not ratified it. The OSCE Declaration, according to which Russian forces had to leave the Transnistrian region till 2002, was adopted at Istanbul summit in 1999. Right after the summit the Russian troops were reduced several times, but after 2003 the Russian Federation refused to continue withdrawal of its contingents (Wolff, 2012: 16). Entire withdrawal of the Russian troops from Transnistria is not in the interest of the Kremlin as it would mean a loss of its position there. Russia is hiding behind the argument that the main function of its Operational Group is to guard ammunition, but it is just a cover of strategic plans of the Russian Federation in Transnistria.

Except the presence of the Operational Group of the Russian Forces, Russian military is a part of peacekeeping mission which emerged there according to the Agreement on Principles of Peace Regulation of Armed Conflict in the Transnistrian Region of the Republic of Moldova signed by the Presidents of Russia and Moldova Boris Yeltsyn and Mircea Snegur on the $21^{\text {st }}$ of June 1992 in Moscow. Peacekeeping mission in Transnistria consists of 1,200 peacekeepers almost evenly divided between Russia, Moldova and Transnistria. In addition to them, there are 10 Ukrainian observers (Hetmanchuk, Litra, Tuhui, Churia, 2014: 21). The main task of peacekeepers is to control the region along the Dnister River with 4-5 kilometers width and 225 kilometers length and also Bendery region (Nikitin, 2018: 271). The authors consider that concerning peacekeeping contingent Russia and Moldova are approximately on equal footing, but concerning presence of the remnants of the former $14^{\text {th }}$ Soviet Army on the territory of Transnistria Russia is in the prevailing position. It is not beneficial to Moldova and Ukraine as neighbours of Transnistria.

Russian military in Transnistria is intended to show Russian dominance there and gives the Russian Federation political leverage on Chisinau. It is connected with the 
most favourable for Moscow future status of Moldova as a neutral country. One of the Russian aims is to prevent Moldova from joining NATO and location of NATO bases on its territory (Wolff, 2012: 17). Transnistria plays a leading role in the confrontation between Russia and NATO in the southeast direction. It facilitates Russian influence over Moldovan authorities, opens opportunities to have impact on Ukraine and creates the basis for Russian domination in Eastern Europe (Cebotari, Budurina-Goreacii, 2017: 35-36). From the point of view of Stephanie Pezard, Katya Migacheva and Brenna Allen, Russian military deployment helped Transnistria to maintain its status as a separatist territory and promote internal instability in Moldova (Pezard, Migacheva, Allen, 2020: 3). In addition to this, Russia pursues its interests of providing some sort of border for protection and springboard for a possible offensive by possessing military troops in Transnistria (Gridina, Frotveit, 2020: 236). Matthew Crandall regards that "Russia's continual military presence in the Transnistrian Region of Moldova has given Russia significant leverage in supporting the Transnistrian regime" (Crandall, 2012: 3). Even though local authorities are loyal to Russia, they are predisposed to independent politics. Moreover, Russian military in Transnistria "is a basis to carry out radar intelligence against Ukraine, a bridgehead for destabilization of Odessa oblast and a channel for penetration of Russian sabotage and reconnaissance groups" into Ukraine (Kravchenko, 2017). Thus, functions of the Russian military in Transnistria are multiple. Russia will hardly withdraw its troops from this de facto state voluntarily. Only its internal weakening and severe loss of its position on the international arena could force the Russian Federation to change its policy in Transnistria concerning military sphere. Possibility of changing of the Russian military policy in Transnistria under internal and external factors can be proved by drawing parallels with the circumstances of the Soviet withdrawal from the Eastern Germany at the beginning of 1990s. It was provoked by difficult domestic political situation in the USSR and inability of the Soviet Union to finance its troops there. Collapse of the USSR and fall of the Berlin Wall contributed to withdrawal of them over the next few years.

The Operational Group of the Russian Forces in the Transnistrian Region of the Republic of Moldova carries out military exercises on the territory of Transnistrian de facto state which the Moldovan government regards illegal. Since 2014 Russian troops hold in Transnistria about 400 military exercises a year involving the Operational Group of the Russian Forces, the Transnistrian armed forces and the Russian peacekeeping contingent (Litra, 2020: 4). In order to force Russian army withdrawal from Transnistria, Moldova should lead persistent government policies. As Moldova's official position depends on political forces coming to power, there is no "the only state project" on this question (Dlia vyvedennia, 2019). In November 2020 pro-Western Maia Sandu was elected as a President of Moldova. Compared to the previous President of Moldova Igor Dodon, who was very much oriented on Russia, Sandu took a tougher stance concerning withdrawal of Russian troops from Transnistria, stressing on it in most of her speeches to the international audience. The position of the Russian Federation on this issue is that the Russian government will not go for any changes concerning presence of its troops and weapons on the territory of Transnistria. The official Chisinau does not have enough tools to force Russia to withdraw its troops from there. Additionally, the Transnistrian authorities are interested in Russian military 
presence on the territory of this breakaway republic (Necsutu, 2021). The President of Transnistria Vadim Krasnoselsky called the issue on withdrawal of Russian military from the region "an artificial problem" (V Pridnestrove, 2020a). Maia Sandu has a special view concerning the peacekeeping forces on the territory of Transnistria. She claims that the peacekeeping mission should be replaced by a civilian one under the auspices of the OSCE. In response to this, the Minister for Foreign Affairs of the Russian Federation Sergey Lavrov considers that the Russian peacekeepers are located there according to international solutions (Sandu, 2020).

In recent years rotation of Russian military is complicated by the Ukrainian government abolishment of the agreement signed in 1995 on military transit from the Russian Federation to the Transnistrian region. The reason for this was deterioration of relations between Russia and Ukraine after destabilization of the situation in Eastern Ukraine. Because of the aggravation of the situation in Donetsk and Luhansk oblasts of Ukraine and Crimea there have been fears that Russia would seize the control over South-Eastern Ukraine in order to get better access to Transnistria (Jović-Lazić, Kuvekalović-Stamatović, 2020: 35; Vardanean, 2018: 34-35). The authors consider that Ukrainian firm position concerning transit of Russian troops through its territory significantly constricts Russian possibilities in military sphere in Transnistria. The activity of the Russian Federation to a certain extent depends upon the level of loyalty of Ukraine to it due to the absence of common border between Russia and Transnistria.

Thus, Russian military presence in Transnistria gives the Kremlin an opportunity to control the situation in Transnistria and demonstrates its interests there. Of particular concern is the Operational Group of the Russian Forces in the Transnistrian Region of the Republic of Moldova. Although its deployment is motivated by guarding ammunition in Kolbasna, it follows far-reaching plans on retaining Russian influence on Transnistria. Moldova has not reached the Russian troops withdrawal from Transnistria for many years as the attitude on this question fluctuated from negative to loyal depending on particular government coming to power in the country.

\section{RUSSIA AS A MEDIATOR OF THE TRANSNISTRIAN CONFLICT RESOLUTION}

Uncertain position of Transnistria on the international arena is connected with unresolved conflict between Transnistrian separatist territory and Moldovan central government. Russia is one of the mediating parties in the process of conflict settlement. To a certain extent Russia's mediator role demonstrates that its interests there are recognized internationally (Pezard, Migacheva, Allen, 2020:3). A starting point for the Russian participation in negotiation process was laid by the abovementioned agreement signed on the $21^{\text {st }}$ of June 1992 in Moscow. The document defined the first negotiating format. It got a name of $1+2$ format in which Russia was mediator and guarantor for the peace settlement, Moldova and Transnistria were parties to the conflict. Later, in 1993 and 1995 the format was widened, and the CSCE (OSCE) and Ukraine assumed a status of mediators and guarantors. This led to the emergence of $3+2$ format. In 2005 
the USA and the EU joined the negotiation process as observers, and $5+2$ format was formed (Haritonova, 2019: 210-213).

Russia was an active negotiator and initiator of conflict resolution mechanisms till the end of 2003. On the $8^{\text {th }}$ of May 1997 Memorandum on Bases of Normalization of Relations Between the Republic of Moldova and Transnistria was signed by the Presidents of Moldova, Transnistria, Russia and Ukraine. It went down in history as the Primakov Memorandum after the last name of its author Yevgeny Primakov, then Minister for Foreign Affairs of the Russian Federation. The main idea expressed in the document was foundation of "common state in the borders of the former Moldavian SSR" (Mospanov, 2017). According to the document Transnistria would have a right to establish independent international contacts in economic, cultural, scientific, and technological spheres. It would also have an opportunity to take part in the realization of foreign policy of Moldova "in matters concerning its interests" (Mospanov, 2017). The Memorandum can be evaluated as an attempt to converge Transnistria and Moldova. Its realization would give broad opportunities for Transnistria in international sphere, but at the same time it would reduce Moldova's capacity to control its own constituent part.

In 2003 Russia launched an initiative on asymmetric federalization of Moldova known as the Kozak Plan or the Kozak Memorandum, named after the author of the document Dmitry Kozak who was the First Deputy Chief of Staff of the Presidential Administration of Russia. According to this plan, Transnistria and one more region of Moldova - Gagauzia had to receive an autonomy with the right to have their own parliaments, courts and an opportunity to block unwanted bills of Moldovan central government. In this document there was a controversial provision according to which Russian would be regarded "an official language," while Moldovan would be in a status of "a state language." Adopting the document would lead to the overrepresentation of minorities in the political life of Moldova as they would have an opportunity to prevent acceptance of any decision of Moldovan government not suitable for them (Vacaru, 2006: 913-920). As the idea of the Kozak Plan would lead to too-extensive rights of Transnistria within the Republic of Moldova, there appeared a term "transnistriarization" of this country with a negative connotation (Devyatkov, 2010: 56). The document was a one more confirmation that Russia tried to control the whole Moldova with assistance of Transnistria. Realization of the Kozak Plan would mean that Moldova fell into the Russian sphere of influence for a long period of time. Russia tried to provide such terms of conflict resolution under which Transnistria would have enough power to influence on Moldova's policy. This plan had to be a guarantee that Moldova will not implement its idea of unification with Romania which was popular among Moldovans at the beginning of 1990s.

The Transnistrian government was satisfied with the document but made some adjustments to it concerning the terms of Russian military presence on the territory of Transnistria, which had to be prolonged for 30 years instead of 20 years proposed in the Kozak Plan, and a status of the Russian language as a state language. The Moldovan President Vladimir Voronin characterized the Kozak Plan as a compromise which could be implemented in practice, but at the last moment denied signing it. It is very probable that he changed his attitude under the influence of Moldovan 
opposition forces, OSCE, USA, and EU. Later he expressed an opinion that signing this document would be a "strategic error" for the Republic of Moldova. Voronin also blamed Russia in providing support of the Transnistrian regime (Vacaru, 2006: 914; Skordas, 2005: 35-36). As follows, interests in Transnistria of many geopolitical players determined further development of this unrecognized republic. This time success was on the side of Western countries using their leverage not to make Moldova dependent on Transnistria.

The Russian Federation tried to reach agreement with Chisinau government to obtain permission of its military presence in Moldova and to achieve the Transnistrian conflict resolution on Russian terms. Russia's task was to find instruments for pressure on Moldova to prefer membership in Eurasian integration projects instead of European integration vector of development (Rogstad, 2016: 18).

Notwithstanding the attempts were made to achieve common solution on the Transnistrian problem, the parties have not managed to settle it. The work of the $5+2$ format was suspended temporarily because of different positions of the conflicting parties. The longest pause in work of this format lasted from 2006 till 2011. During 2010 and 2011 the position of Russia was not stable and "fluctuated between a pressure on the Transnistrian leadership and delaying a decision of resumption of negotiations in the 5+2 format" (Sekrieru, 2013: 8). The negotiation process was imperiled after Russian aggression in Ukraine in 2014 as deterioration of relations between the two mediators - Russia and Ukraine, has a negative impact on conflict resolution in Transnistria.

Although the Kozak Plan was not implemented in 2003, in fact its idea is promoted step-by-step under the hidden names "small steps" or "confidence building measures" (Litra, 2018: 3). This strategy, aimed at establishing close ties between Transnistria and Moldova, became possible due to some documents adopted within the 5+2 format. In June 2016 Berlin protocol was signed. The parties achieved agreement on such questions as apostilisation of Transnistrian diplomas; use of vehicles with number plates issued in Transnistria; telecommunications and connections between Moldova and Transnistria; cooperation in the area of meteorology and protection of natural resources in the Dnister River basin; progress concerning criminal cases, especially the exchange of updated lists of existing criminal cases (Protokol, 2016). In November 2017 Vienna protocol was signed. In the document the participants noted the achieved progress on the questions of affixing apostille on the documents on education issued in Transnistria; organization of cooperation in the sphere of telecommunications; maintenance of functioning of the Moldavian schools with education in Latin script; use of agricultural lands in Dubossary region; reopening of the bridge through the Dnister River between the villages Gura-Bykului and Bychok (Protokol, 2017). The Rome protocol signed in May 2018 expressed a consent on the necessity of implementation of agreements achieved before (Protokol, 2018). The abovementioned documents focus on bringing Moldova and Transnistria closer to one another and could be seen as a way to achievement a special status of Transnistria in Moldova, which is the most favourable variant of conflict resolution for Russia. The authors suppose that until the time of unification of Moldova with its breakaway territory Russia is satisfied with preserving a status quo in Transnistria with further improvement of relations between Transnistria and its parent state. 
In 2019 negotiations between Transnistria and Moldova were not successful. Chisinau refused to sign the final Bratislava protocol composed within the $5+2$ format. A number of meetings of expert (working) groups was three times lower than during 2018 , and a number of meetings of representatives on political questions was 10 times lower than during the previous year. One of factors influencing on it was connected with a series of shifts of governments in Moldova during 2019 (O peregovorah, 2019). In 2020 the negotiation process lost its functionality as for the first time since 2007 the participants of $5+2$ format have not met in full even for consultations. Additionally, COVID-19 pandemic influenced negatively on intensity of contacts of negotiating parties (Otchet, 2021).

Besides inconsistencies between negotiating parties, an important factor which hindered the resolution of Transnistrian conflict was Moldovan balancing between Russia and Romania. In 1990s Moldovan political elites considered the idea of unification with Romania as a way to integration with the European Union. Reluctance of Moldovans to lose their state and refuse reintegration of Transnistria were the main obstacles to strengthening the idea of further Moldovan-Romanian rapprochement (Javir, 2018: 80). The absence of clear foreign policy course of Moldova did not give an opportunity to resolve Transnistrian problem.

Thus, the conflict settlement is internationalized due to the participation in it of many international actors including Russia. Degree of intensification of negotiating process depends on many factors, including relations between Russia and other members of the $5+2$ format, mood of Moldovan leadership, relations between Tiraspol and Chisinau. Russia was an active participant of the $5+2$ format till 2003 wishing to bring Transnistria and Moldova closer to one another. Later its efforts to settle the conflict were lesser. Russia hopes to achieve its goals on convergence of Tiraspol and Chisinau through the implementation of the strategy called "small steps." Military presence gives the Russian Federation additional influence on negotiating format.

\section{RUSSIAN POLICY IN TRANSNISTRIA IN CULTURAL, SOCIAL AND ECONOMIC SPHERES}

Russia has a great impact on cultural, social and economic life of the population of Transnistria. On the territory of Transnistria three largest ethnic groups - Russians, Ukrainians and Moldovans live almost in equal proportions. According to the Constitution of Transnistria, there are three official languages in this de facto state - Moldovan, Russian and Ukrainian, but Russian prevails over the other in many spheres (Hammarberg, 2013: 35). The main language of the Transnistrian political elite is Russian. As the language forms self-consciousness of any group of people, under the influence of Russian language among citizens of this de facto state there has developed a special type of it, when they identify themselves with Transnistria from one side and with the Russian Federation from the other.

Among the main elements of Transnistrian identity is the "Russian World," a geopolitical concept of which is widely popular among common Russians as well as among many other people outside of Russia. It is also reflected in official documents of 
the Russian Federation. Thus, according to the Concept of Foreign Policy of the Russian Federation accepted in 2016, one of its tasks is defending "rights and legitimate interests of the Russian citizens and compatriots leaving abroad, including in various international formats" (Koncepciya, 2016). By this provision Russia justifies its activity on the territory of the former USSR including Transnistria.

The population of Transnistria sympathizes Russia as older people remember Soviet past when Moldova was a rich republic of the USSR in comparison with some other republics. Nostalgia for those times makes Transnistrians to gravitate to Russia because they consider it a successor of the Soviet Union. An additional factor forming political vector of Transnistria is connected with the fact that the representatives of three prevailing ethnic groups are for rapprochement with the Russian Federation. Persistent Russian policy, based on declarations about protection of Russian-speaking population of Transnistria, is aimed at penetration into Moldova's internal affairs.

Moscow influences on the population of Transnistria by the institute of the Russian citizenship. It is granted by the Point of the Consular Service of the Russian Federation located in Tiraspol. This point is a constituent part of the Russian Embassy in Moldova. On the territory of Transnistria 220,000 citizens with Russian passports live (Vadim Krasnoselsky, 2019). Russian citizenship gives Transnistrians an opportunity to take part in the Russian elections and receive Russian assistance. Considering the fact that Transnistria is demographically small, its domestic market is not developed enough and it does not have rich row material potential, Transnistria can hardly rely only on its forces (Calus, 2013: 1). Thus, Russian assistance reduces the burden of the Transnistrian budget and strengthens loyalty of the Transnistrian citizens to the Russian policy. Russia by such activity has an opportunity to show that it views Transnistria as its own sphere of influence.

Russian investments to the region were high till 2014, but after the Russian aggression in Ukraine Moscow reduced its financial assistance, still performing a few social projects directed on demonstration of advantages of cooperation with Russia (Litra, 2020: 4). Almost 150,000 retirees of Transnistria receive the so-called pension supplement from Russia. By 2015 it was \$ 15 per one person, but in 2015 it was cut to $\$ 9$ (Kermach, 2017: 15; Necsutu, 2019). Thomas de Waal names possible reasons of reduction of direct financial subsidies from Moscow. First, spending for Crimea and the armed conflict in Donetsk and Luhansk oblasts of Ukraine is high. Second, Russia regards that the largest private company of the region called Sheriff could make some social payments. Third, non-recognition of Transnistria has a negative influence on economic transfers there (De Waal, 2018: 44). Periodically Russian humanitarian tranches for Transnistrian retirees were suspended and delayed. Transnistrian authorities explained them by technical inconsistencies with Moscow. In July 2020 pension supplement to Transnistria was not sent by the Russian Federation, but in December the retirees have got an opportunity to receive the money as the next tranche arrived in the state. For the Kremlin it is important to acquire loyalty of Transnistrian citizens along with demands of Maia Sandu on Russian troops withdrawal from Transnistria (Moskva, 2020).

Since 2005 Russia supplies free gas to Transnistria, but it is regarded by Moscow as a debt of Moldova. This position corelates with the official position of the Rus- 
sian Federation that Transnistria is a constituent part of the Republic of Moldova, and that Moldova should make a repayment for it. However, full repayment in the nearest future by Moldova itself will hardly be made. Version that a third party like the EU will cover this debt is also unlikely. More realistic is "a full or partial cancellation or (re-)structuring of this debt as part of a broader settlement deal addressing some of Russia's key concerns (such as Moldovan neutrality and security of Russian investments)" (Wolff, 2012: 21). Gas debt of Transnistria is about $\$ 7.5$ billion (Flyahov, 2020).

Granting of Russian passports, financial assistance to Transnistrian retirees and free gas supplies are the most valuable examples of Russian assistance. Notwithstanding it, in academic research there is an opinion that although Russia is a sponsor of Transnistria in many spheres, it is not interested in its prosperity as it realizes that while Transnistria is economically dependent on Moscow, Russia is able to control this unrecognized republic (Calus, 2013: 1). This idea seems to be close to reality as poor de facto states usually move towards countries subsidizing them for political commitment. Limited capacity of Transnistria in internal and external policy pushes it to be an active recipient of Russian assistance.

The Russian Federation provides informational control of Transnistria as Russian television and radio are widespread there. Along with printed literature they have a great impact on the public consciousness in Transnistria. Moreover, Russian business is well positioned in Transnistria. Some companies in Transnistria are closely linked with the military-industrial complex of the Russian Federation which provides direct and indirect control over them (Goltsov, 2020: 163). Thus, Russia influences Transnistria through both information and economic means.

Transnistria is export-oriented. For many years Russia was a main partner of it in export sphere, but in recent years exports to Russia decreased from $\$ 909$ million between 2007 and 2010 to $\$ 232$ million between 2015 and 2018. Moreover, these figures continue to decrease. It is connected with the fact that Transnistria strengthened export relations with member states of the EU. More than $70 \%$ of Transnistria's exports go to the European market (Necsutu, 2019). There is a situation that Transnistria is for Eurasian integration but has closer trade relations with European countries than with Russia.

In 2019 the Russian Federation was on the third place after Moldova and Ukraine in the structure of Transnistrian export with a share of $13.2 \%$ or $\$ 86.7$ million. In the structure of Transnistrian import Russia was on the first place with $46 \%$ share or \$ 554 million (Statistika, 2019). In 2020 Russia remained among the main buyers of Transnistrian goods remaining on the same place. Its share was $11.0 \%$ or $\$ 69.9$ million. The Russian Federation also preserved its status of the main supplier of goods for Transnistria. Its share in 2020 was $38.3 \%$ of Transnistrian total imports or \$ 403.6 million. The main item was energy, constituting $76.1 \%$ of the Russian export to this de facto state (Vneshnyaya torgovlya, 2021).

Russia tries to strengthen its economic power in Transnistria. One of examples of its activity is "Russian Trade Project." Agreement on its establishment was signed by the Agency on Investments of the Pridnestrovian Moldavian Republic and the Council on Development of Foreign Trade and International Economic Relations of the Rus- 
sian Federation at international economic forum in St. Petersburg in 2019. The aim of the project is to promote goods and services on Russian market and to strengthen economic ties with Russia. In the framework of this project, it is planned to carry out presentations of Transnistrian manufacturers and organize their participation in Russian exhibitions and forums (V Pridnestrove, 2019). Additionally, Russia is a supplier of humanitarian aid to Transnistria. At the beginning of 2021 Transnistria received 90 million Russian roubles intended to agrarian units which have suffered greatly as a result of 2020 drought (V Pridnestrove, 2020b).

As follows, Russia influences on the Transnistrian region ideologically through its concept of the "Russian World." Citizens of Transnistria are applicants of Russian passports which give them an opportunity to receive Russian aid. Among important spheres of Russian activity are financial assistance to Transnistria and export-import relations with the region. The Russian Federation was more active in social and economic spheres before 2014 when it had much more resources to help this unrecognized republic. Exhausted by sanctions, the Kremlin started losing its position there despite the fact that Transnistria is pro-Russian and ready to intensive cooperation.

\section{TRANSNISTRIAN PRESIDENTS' POLICY TOWARDS CONVERGENCE WITH THE RUSSIAN FEDERATION}

The post of president of Transnistria is endowed with extensive powers in external relations policies. President represents this de facto state on the international arena and directs its foreign policy. Transnistria has been under the governance of three presidents - Igor Smirnov (1991-2011), Yevgeny Shevchuk (2011-2016) and Vadim Krasnoselsky (2016-now). Igor Smirnov had been elected as a president of Transnistria four times, and his power was steadily expanded during the period of his governance. Smirnov regarded the relations with the Russian Federation one of the main priorities of Transnistria. Smirnov's regime stressed on the russification of Transnistria, presenting it as a part of so-called "Slavic civilization" and important military outpost of the Russian Federation. Representatives of the Transnistrian government tried to establish personal contacts with Russian political elites on various levels and to obtain support of Russian public and nationalist politicians. Moreover, Transnistria was economically bound with Russia as many objects of regional industry were sold to Russian companies which were expected by Transnistrian authorities to defend local interests (Kosienkowski, 2012a: 24-26).

The last presidential term of Smirnov was characterized by holding in 2006 a referendum "on independence and joining the Russian Federation" which demonstrated rejection by Transnistrians the idea of unification with Moldova. On the question concerning a course towards independence of Transnistria and its further free unification with the Russian Federation $97.2 \%$ of voters answered positively (Volkova, 2009: 148). However, Transnistria lacked political resources to implement a will of its citizens, and Russian-Transnistrian cooperation degraded till the end of Smirnov's presidency. Russia did not approve "volatility of Transnistrian leadership concerning vector of foreign policy and lack of Tiraspol's clear understanding of relations with 
its neighbours" (Vneshnyaya politika, 2016). Although Russian authorities cooperated with Smirnov, they regarded him unreliable person who expressed contradicting ideas about the future of Transnistria: confederation / federation with Moldova, joining Russia-Belarus Union, unification with Ukraine, independence and unification with Russia (Kosienkowski, 2012b: 56-57). That is why when in 2011 Smirnov announced that he would run for the presidency for the fifth term, Russian authorities signaled that Moscow wished to see a change of power there (Kolsto, Blakkisrud, 2017: 508). Russia planned to change him for a more cooperative leader and pressed Transnistria before the elections. It "suspended provision of its financial assistance to Transnistria, raised Tiraspol the issue about gas debt of the region to Gazprom and began to persecute Smirnov's family through its system of law-enforcement authorities" (Sekrieru, 2013: 8). The authors suppose that variable Smirnov's position on the future of Transnistria was connected with his reluctance to lose authority in Transnistria. His main task was to defend his personal interests on maintaining power. Transnistrian status was one of the issues on which Smirnov manipulated in order to keep Russia in tension but at the same time to get as much support from it as possible.

During the presidential elections in December 2011 pro-Kremlin candidate Anatoly Kaminsky lost the race to an independent candidate Yevgeny Shevchuk. Initially Russia regarded Shevchuk unpredictable and made some steps to gain his sympathy. Until the spring of 2012 Moscow withheld its financial assistance trying to press on Transnistrian leader but later on strengthened its social and economic ties with Transnistria. Among other steps was direction a staff member of Federal Security Service of the Russian Federation for the post of the Deputy Head of State Security Committee of Transnistria and modernization of a former military airport in Tiraspol. Such activity has led to coordination of Transnistrian policy with Russia (Sekrieru, 2013: 8-10). As follows, Russian activity indicated that it wanted to see its puppet as a head of de facto state. Carrot-and-stick policy gave its results very soon and Shevchuk became a very close ally of the Kremlin.

In the Concept of Foreign Policy of the Pridnestrovian Moldavian Republic accepted on the $20^{\text {th }}$ of November 2012 it is noted that relations with the Russian Federation are viewed as a key political direction. "Historic, cultural and economic ties between Russia and Transnistria within the united Russian World" are named as a main ground of it (Koncepciya, 2012). The Concept of 2012 differs from the previous one accepted in 2005 concerning the priorities of Transnistrian foreign policy as in the Concept of 2005 good-neighbourly relations with the Republic of Moldova were determined as the first and the most important political vector. Cooperation with the Commonwealth of Independent States as well as establishing relationships with its member states, especially with Russia and Ukraine, was outlined as a second one direction (Vneshnyaya politika, 2012). Shifting priorities of foreign policy of the Transnistrian state showed its distancing from parent state and movement towards Russia. Further cooperation between the two countries was a practical evidence of realization of a new concept.

In 2016 Shevchuk was defeated at the presidential elections because he made a number of tactical errors. Among them confrontation with the Supreme Council, business elites and a part of the population of Transnistria. Population was dissatisfied 
with temporary withholding of $30 \%$ of wages and retirement. This led to the election of Vadim Krasnoselsky as a president, being supported by the largest in Transnistria private company Sheriff (Galinskij, Galinskij, 2018: 66).

Krasnoselsky views Transnistria as a part of the former Russian Empire. Concerning the idea of unification with Russia he relies on the data of the referendum held in 2006 and regards that unification is impossible before recognition of Transnistrian independence by the international community. Transnistria should become a member of the United Nations and other international institutions first, after that it will act according to the aspirations of its people (Sydorenko, 2019). The authors argue that it will be difficult for Transnistria to achieve its twofold aim in the nearest future. First, broad international recognition of this de facto state is possible only with the consent of the parent state Moldova. Second, unification with Russia is complicated by geographic distance between the Russian Federation and Transnistria.

In the Strategy of Development of Transnistria for 2019-2026, adopted by the President Krasnoselsky on the $12^{\text {th }}$ of December 2018, one of the main elements of development of Transnistria is realization the outcome of the referendum of 2006. "Further strengthening and broadening the spectrum of political and diplomatic contacts, cooperation in the sphere of peacekeeping and security, development of trade and economic ties and increase of mutual trade, building of cultural and humanitarian linkages, interactions through social institutions" are considered as the most relevant in relations with the Russian Federation (Strategiya, 2018).

Enhanced cooperation with the Russian Federation remains a priority of Vadim Krasnoselsky. Thus, in January 2020 the Transnistrian President accompanied with the Minister for Foreign Affairs of Transnistria Vitaly Ignatiev paid a working visit to the Russian Federation. A few their meetings with the Russian authorities were held in Moscow. The parties discussed negotiation process with Moldova, questions of bilateral cooperation between Russia and Transnistria, especially in the sphere of realization of social and humanitarian projects. In December 2020 Krasnoselsky and Ignatiev met with the Russian parliamentarians, senators, Deputy Chief of Staff of the Presidential Administration of the Russian Federation Dmitry Kozak and Deputy Minister for Foreign Affairs Aleksandr Pankin in Moscow. The issues on social and humanitarian support of Russian citizens in Transnistria, some aspects of trade, economic and cultural relations between the Russian Federation and Transnistria were raised. Negotiation process between Transnistria and Moldova, certain aspects of peacekeeping mission, some arrangements in medical sphere concerning preventing the spread of COVID-19 on the territory of Transnistria were discussed (Otchet, 2021). Krasnoselsky coordinates development of Transnistria with Russia in different spheres, spreading his contacts at the state level, receiving support from Russia, and fostering dialogue and cooperation at the bilateral level.

Consequently, none of three presidents demonstrated pro-Western course concerning foreign policy of Transnistria. Smirnov managed to hold a referendum on the future of the region. Shevchuk was an independent candidate at the elections but very soon started active cooperation with the Russian government. Krasnoselsky became a continuer of his predecessors regarding vector of development of Transnistria focusing on rapprochement with Russia. 


\section{NON-RECOGNITION OF THE PRIDNESTROVIAN MOLDAVIAN REPUBLIC BY THE RUSSIAN FEDERATION}

Transnistria is not recognized by the Russian Federation as an independent state. Although Russia provides assistance to it in various spheres, its policy is characterized by ambiguity concerning the question of diplomatic recognition of Transnistria. As Ernest Vardanean points out, "officially, Moscow supports Moldovan territorial integrity. In practice, Russia gives overall support to Transnistria" (Vardanean, 2018: 46). By such a strategy the Russian Federation does not deteriorate relations with Moldova and at the same time partly controls its development, being present in Transnistria.

The Transnistrian government tries to move towards Russia's recognition of Transnistria through strengthening its political ties with the Russian Federation. In 2005-2012 they had been realized through public organization "Transnistria" represented in Moscow. In 2019 on the territory of the Russian Federation there was registered public organization "Fund of Development of Social and Cultural Links "Transnistria." According to the position of the Transnistrian government, it is Official Representation of the Pridnestrovian Moldavian Republic in the Russian Federation and is a structural unit of the system of institutions of diplomatic service of Transnistria. Among the main tasks of this body is establishing of cultural, social, economic, and other links between Transnistria and Russia (Otkryto, 2019). This representation is seen by the Transnistrian government as a step to the future recognition of Transnistria by the Russian Federation.

Opening of the Transnistrian representation in Moscow contributes to closer bilateral relations, but official recognition of Transnistria by the Russian Federation is hardly possible in the present situation. From the point of view of Igor Putincev, Russia's recognition of Transnistria would lead to "serious destabilization of the situation in the region, possible break up of relations between Russia and Moldova, significant deterioration of Russia's relations with Ukraine and Romania, and to the emergence of new disagreements with the EU and the USA" (Putincev, 2010: 1). In academic literature there is also an opinion that Russia holds a recognition of Transnistria "to the time of possible escalation of the conflict" (Gushchin, Markedonov, 2016: 6). Similar scenario was used by it in Abkhazia and South Ossetia in 2008. By this logic, deterioration of the situation in Transnistria could lead to activization of the Russian Federation in the region and the establishment of diplomatic relations with it.

According to the official position of the Russian Federation, recognition of Transnistria is not included in its plans. On the $14^{\text {th }}$ of April 2014 the Supreme Council of Transnistria requested Russian President Vladimir Putin for recognition of the sovereignty of Transnistria and permission of its unification with the Russian Federation. However, Russian Foreign Minister Sergey Lavrov reaffirmed that "Russia respects the sovereignty and territorial integrity of Moldova" (Baar, Baarová, 2017: 279). In the Concept of Foreign Policy of the Russian Federation adopted by the Russian President Vladimir Putin on the $30^{\text {th }}$ of November 2016, Russia stands for the regulation of the Transnistrian problem "on the basis of respecting sovereignty, territorial integrity and neutral status of the Republic of Moldova in determining a special status of Transnistria" (Koncepciya, 2016). It should be taken into consideration that position conveyed 
in official documents and statements does not always coincide with actions of the Russian Federation. Sometimes Russia consciously reassures international community in order to have free hand on its policy.

One of the main geopolitical goals of the Russian Federation on the post-Soviet space is spreading its influence and drawing into orbit of its interests more territories. This applies not only to Moldova, but also to Ukraine where Russia uses similar means. In both countries Russia tries to implement its geopolitical concept of the "Russian world" and positions itself as a defender of Russian-speaking population. The policy of "passportization," information propaganda, military presence on territories not controlled by parent states, attempts to provide the influence of separatist territories on foreign policy course of the two countries are among the main instruments of the Russian policy. Even without official incorporation of the territories of Donetsk and Luhansk oblasts to the Russian Federation and diplomatic recognition of Transnistria, it will try to destabilize political situation in Moldova and Ukraine in order to prevent their European and Euro-Atlantic course.

\section{CONCLUSIONS}

Transnistria has a strategic importance for the Russian Federation for many reasons which are of local and regional character. Russia's politics there corelates with its activity in different parts of the post-Soviet space connected with its expansionist ambitions. Russian strategy is based on the use of ideological and material means which are reflected in its activity in military, political, cultural, social, and economic spheres.

Military presence of Russian troops on the territory of Transnistria is aimed at demonstration of Russian superiority over Moldova. Military factor should influence not only on attitudes to Russia of the population of Transnistria, but also predetermine geopolitical choice of Moldova. Russian withdrawal repeatedly sounded in the speeches of Moldovan politicians however the case did not move beyond rhetoric. Probably Russia would change its approach to military aspect in Transnistria due to the international situation or internal factors.

Russia expects Transnistrian conflict resolution in $5+2$ format which was very close to it at the beginning of 2000s, being one step away from including Transnistria to the territory of Moldova in terms of wide autonomy with decisive vote on forming foreign policy course of Moldova. It would predetermine the future of Moldova as Russian satellite, regarding the mood of Transnistrian population having opportunity to block any foreign policy decision not suitable for Transnistria. There is a problem connected with the absence of clear long-term position of Moldova concerning Russian ambitions on its territory due to the diversity of vectors of Moldovan authorities coming to power at different times.

Moscow can easily secure influence in Transnistria regarding the fact that this de facto state is inhabited by pro-Soviet population seeing in Russia an opportunity of restoration of the USSR. Material aid to the population strengthens favorable attitude of the population to the Russian Federation which can be regarded by the citizens of Transnistria as their patron state. Relations in trade sphere highlight the importance of 
Russia as a valuable partner. Informational influence through Russian-language media plays a considerable role in self-identification of the people of Transnistria who regard themselves as a part of the "Russian World."

Trajectory of Russian activity in Transnistria depends not only on the attitudes of the population of this unrecognized state and Moldova, but also on Ukraine as a close neighbour of Transnistria; OSCE, USA and EU interested in political commitment of Moldova to the West; Romania which does not want Moldova to be drawn into Russia's sphere of influence.

\section{REFERENCES}

Baar V., Baarová B. (2017), De facto states and their socio-economic structures in the post-Soviet space after the annexation of Crimea, "Studia z Geografii Politycznej i Historicznej", Vol. 6, DOI: $10.18778 / 2300-0562.06 .12$.

Beyer J., Wolff S. (2016), Linkage and leverage effects on Moldova's Transnistria problem, "East European Politics", Vol. 32, No. 2.

Buttin F. (2007), A Human Security Perspective on Transnistria Reassessing the Situation within the "Black Hole of Europe", "Revue de la Sécurité Humaine/Human Security Journal", Issue 3.

Calus K. (2013), An aided economy. The characteristics of the Transnistrian economic model, "OSW Commentary", No. 108.

Cebotari S., Budurina-Goreacii C. (2017), Specifics of the Russian Federation interests in Moldova in the context of new geopolitical changes, "Ante Portas - Studia nad Bezpieczeństwem", No. 1 (8).

Crandall M. (2012), Hierarchy in Moldova-Russia Relations: the Transnistrian Effect, "Studies of Transition States and Societies", Vol. 4, Issue 1.

Devyatkov A. (2010), "Memorandum Kozaka" v istorii pridnestrovskogo uregulirovaniya, "Izvestiya Altajskogo gosudarstvennogo universiteta", No. 4-2.

De Waal Th. (2018), Uncertain Ground. Engaging With Europe's De Facto States and Breakaway Territories, Washington.

Dlia vyvedennia (2019), Dlia vyvedennia rosiiskykh viisk z Prydnistrovia potribna yedyna polityka - ministr oborony Moldovy, "ZN.UA", 06.05.2019, https://dt.ua/WORLD/dlya-vivedennya-rosiyskih-viysk-z-pridnistrov-ya-potribna-yedina-politika-ministr-oboroni-moldovi-310368_html (22.07.2020).

Doroshko M. (2012), Heopolitychni interesy zovnishnikh syl u zoni Prydnistrovskoho konfliktu, "Heopolityka Ukrainy: istoriia i suchasnist", Vyp. 7.

Flyahov R. (2020), Moldaviya otkazyvaetsya priznavat dolgi za gaz, "gazeta.ru”, 01.12.2020, https:// www.gazeta.ru/business/2020/12/01/13382233.shtml (21.02.2021).

Galinskij I. N., Galinskij Y. O. (2018), Pridnestrove: problemy stanovleniya i razvitiya gosudarstvennosti, "Vlast", No. 5.

Goltsov A. (2020), Geopolitics of the Russian Federation Regarding the Republic of Moldova, "Cogito. Multidisciplinary Research Journal", Vol. XII, No. 3.

Gridina I., Frotveit M. (2020), The Problem of the Unrecognized States of the Post-Soviet Space in the Politics of the Russian Federation, "Skhidnoievropeiskyi Istorychnyi Visnyk", Issue 16.

Gushchin A. V., Markedonov S. M. (2016), Pridnestrove: dilemmy mirnogo uregulirovaniya, No. 1, Moskva, https://russiancouncil.ru/upload/Transnistria_policybrief1.pdf (09.02.2020). 
Hammarberg Th. (2013), Report on Human Rights in the Transnistrian Region of the Republic of Moldova, https://tbinternet.ohchr.org/Treaties/CRC/Shared\%20Documents/MDA/INT_ CRC_IFS_MDA_26228_E.pdf(19.07.2020).

Haritonova N. I. (2019), Rol Rossii v uregulirovanii pridnestrovskogo konflikta (2014-2018 gg.): politicheskie aspekty, "Gosudarstvennoe upravlenie. Elektronnyj vestnik", No. 72, https://cyberleninka.ru/article/n/rol-rossii-v-uregulirovanii-pridnestrovskogo-konflikta2014-2018-gg-politicheskie-aspekty/viewer (29.03.2020).

Hetmanchuk A., Litra L., Tuhui E., Churia K. (2014), Reforma myrotvorchoi misii u Prydnistrovi: peredumova dlia vrehuliuvannia konfliktu, Kyiv.

Javir V. (2018), Intehracijno-dezintehracijni procesy u Moldovi, "Studia Politologica Ucraino-Polona”, Vyp. 8.

Jović-Lazić A., Kuvekalović-Stamatović J. (2020), Permanent Neutrality of the Republic of Moldova - Strategy for Survival Between Russia and NATO?, "The Review of International Affairs", Vol. LXXI, No. 1179, DOI: https://doi.org/10.18485/iipe_ria.2020.71.1179.2.

Kermach R. (2017), The sources of sustainability of the Transnistrian de facto state, "UA: Ukraine Analytica", No. 3 (9).

Kolosov V. A. (2007), Rol 14-j armii v aktivnoj faze pridnestrovskogo konflikta, "Izvestiya vuzov. Severo-Kavkazskij region", No. 3.

Kolstø P., Blakkisrud H. (2017), Regime Development and Patron-Client Relations: The 2016 Transnistrian Presidential Elections and the "Russia Factor", "Democratizatsia. The Journal of Post-Soviet Democratization", No. 25 (4).

Kolstø P., Malgin A. (1998), The Transnistrian Republic: a case of politicized regionalism, "Nationalities Papers: The Journal of Nationalism and Ethnicity", Vol. 26, No. 1, DOI: $10.1080 / 00905999808408553$.

Koncepciya (2012), Koncepciya vneshnej politiki Pridnestrovskoj Moldavskoj Respubliki (20 noyabrya 2012 goda), Ministerstvo inostrannyh del Pridnestrovskoj Moldavskoj Respubliki, http://mfa-pmr.org/ru/Qpj (21.07.2020).

Koncepciya (2016), Koncepciya vneshnej politiki Rossijskoj Federacii (30 noyabrya 2016 goda), Prezident Rossii, http://kremlin.ru/acts/bank/41451/page/1 (24.08.2020).

Kosienkowski M. (2012a), Continuity and Change in Transnistria's Foreign Policy after the 2011 Presidential Elections, Lublin.

Kosienkowski M. (2012b), Is Internationally Recognised Independence the Goal of Quasi-States? The Case of Transnistria, "SSRN Electronic Journal”, DOI: 10.2139/ssrn.2132161.

Kravchenko V. (2017), Rosiia znovu vidmovliaietsia pity z Prydnistrovia, "Dzerkalo tyzhnia", 21.10.-27.20.

Litra L. (2020), Dzerkalne vidobrazhennia: shcho Prydnistrovia mozhe pidkazaty nam pro Donbas?, "Policy Brief", https://rpr.org.ua/wp-content/uploads/2020/01/PB_Moldova_ukr-3.pdf (19.07.2020).

Litra L. (2018), Pastky prydnistrovskoho vrehuliuvannia: yak nam yikh unyknuty?, "Policy Brief”, http://neweurope.org.ua/wp-content/uploads/2018/04/Policy-Brief_Pastky-Prydnistrovskogo_ukr.pdf (19.07.2020).

Moldova v OBSIe (2019), Moldova v OBSIe nahadala: rosiiski viiska nezakonno perebuvaiut u Prydnistrovi, "Ukrinform", 17.05.2019, https://www.ukrinform.ua/rubric-world/2702533-moldova-v-obse-nagadala-rosijski-vijska-nezakonno-perebuvaut-u-pridnistrovi.html (22.07.2020).

Moskva (2020), Moskva podkupaet zhitelej Pridnestrovya na fone trebovanij Sandu o vyvode vojsk $R F$, “Guildhall", 10.12.2020, https://ghall.com.ua/2020/12/10/moskva-podkupaet-zhitelejpridnestrovya-na-fone-trebovanij-sandu-o-vyvode-vojsk-rf/ (21.02.2021). 
Mospanov A. (2017), "Memorandum Primakova” 20 let spustya, "Ritm Evrazii", 12.05.2017, https:// www.ritmeurasia.org/news--2017-05-12--memorandum-primakova-20-let-spustja-30087 (29.03.2020).

Necsutu M. (2019), BIRN Fact-Check: Is Transnistria Really Economically Dependent on Russia?, "BalkanInsight", 23.12.2019, https://balkaninsight.com/2019/12/23/birn-fact-check-istransnistria-really-economically-dependent-on-russia/ (31.03.2020).

Necsutu M. (2020), BIRN Fact-Check: What Must be Done for Russian Forces to Leave Transnistria?, 22.01.2020, https://balkaninsight.com/2021/01/22/birn-fact-check-what-must-bedone-for-russian-forces-to-leave-transnistria/ (20.02.2021).

Nikitin A. I. (2018), Mezhdunarodnye konflikty: vmeshatelstvo, mirotvorchestvo, uregulirovanie, Moskva.

O peregovorah (2019), O peregovorah s Moldovoj, otnosheniyah s mezhdunarodnymi partnerami $i$ "kosovskom precedente", Ministerstvo inostrannyh del Pridnestrovskoj Moldavskoj Respubliki, 27.12.2019, http://mfa-pmr.org/ru/node/7687 (20.06.2020).

Otchet (2021), Otchet Ministerstva inostrannyh del Pridnestrovskoj Moldavskoj Respubliki o prodelannoj rabote za 2020 god, Ministerstvo inostrannyh del Pridnestrovskoj Moldavskoj Respubliki, http://mfa-pmr.org/ru/node/8349 (22.02.2021).

Otkryto (2019), Otkryto oficialnoe predstavitelstvo PMR v Rossii, "REGNUM", 23.01.2019, https:// regnum.ru/news/polit/2557653.html (09.05.2020).

Pezard S., Migacheva K., Allen B. (2020), Russia's Hostile Measures. Combating Russian Gray Zone Aggression Against NATO in the Contact, Blunt, and Surge Layers of Competition. Appendix B: Detailed Case Studies of Russia's Use of Hostile Measures, Santa Monica, https://apps. dtic.mil/sti/pdfs/AD1090554.pdf (19.02.2021).

Popescu N., Litra L. (2012), Transnistria: a bottom-up solution, "Policy Brief", https://ecfr.eu/wpcontent/uploads/ECFR63_TRANSNISTRIA_BRIEF_AW.pdf (25.09.2021).

Protokol (2016), Protokol oficialnogo zasedaniya Postoyannogo soveshchaniya po politicheskim voprosam v ramkah peregovornogo processa po pridnestrovskomu uregulirovaniyu, 2-3 iyunya 2016 goda, Berlin, Ministerstvo inostrannyh del Pridnestrovskoj Moldavskoj Respubliki, http://mfa-pmr.org/ru/zxM (20.06.2020).

Protokol (2017), Protokol zasedaniya "Postoyannogo soveshchaniya po politicheskim voprosam v ramkah peregovornogo processa po pridnestrovskomu uregulirovaniyu”, 27-28 noyabrya 2017 goda, Vena, https://www.osce.org/files/f/documents/5/b/359201.pdf (20.06.2020).

Protokol (2018), Protokol zasedaniya "Postoyannogo soveshchaniya po politicheskim voprosam $v$ ramkah peregovornogo processa po pridnestrovskomu uregulirovaniyu”, 29-30 maya 2018 goda, Rim, http://mfa-pmr.org/ru/pvy (28.08.2020).

Putincev I. S. (2010), Pridnestrovskij kompromiss?, "Vestnik MGIMO Universiteta", No. 1.

Quinlan P. D. (2020), The Impact of the Crisis in Ukraine in 2014 on Moldova, from the Perspective of a Historian, "Cordul Cosminului”, Vol. XXVI, No. 2, DOI: https://doi.org/10.4316/ CC.2020.02.005.

Rogstad A. (2016), The next Crimea? getting Russia's Transnistria policy right, http://eprints.lse. ac.uk (13.03.2020).

Sandu (2020), Sandu prizvala vosstanovit funkcionalnost peregovorov po Pridnestrovyu, "Izvestiya", 08.12.2020, https://iz.ru/1097071/2020-12-08/sandu-prizvala-vosstanovit-funktcionalnostperegovorov-po-pridnestroviu (20.02.2021).

Sekrieru S. (2013), Zatyazhnye konflikty v stranah Vostochnogo partnerstva: mezhdu predotvrashcheniem vojny i postroeniem doveriya, "Neighbourhood policy paper", No. 4. 
Skordas A. (2005), Transnistria: Another Domino on Russia's Periphery?, "Yale Journal of International Affairs", Summer-Fall.

Statistika (2019), Statistika vneshnej torgovli Pridnestrovya v 2019 godu, Torgovo-promyshlennaya palata Pridnestrovya, https://tiraspol.ru/confirmed/statistika-vneshney-torgovli-pridnestrovya/ (24.08.2020).

Strategiya (2018), Strategiya razvitiya Pridnestrovskoj Moldavskoj Respubliki na 2019-2026 gody, 12 dekabrya 2018 g., Tiraspol, http://president.gospmr.org/pravovye-akty/ukazi/ob-utverjdenii-strategii-razvitiya-pridnestrovskoy-moldavskoy-respubliki-na-2019-2026-godi.html (23.07.2020).

Sydorenko S. (2019), "Daiu harantiiu, vid nas ne bude napadu RF na Ukrainu”: interviu lidera nevyznanoho Prydnistrovia, "Ievropeiska pravda", 21.01.2019, https://www.eurointegration. com.ua/interview/2019/01/21/7091796/ (16.07.2020).

Vacaru C. (2006), Resolution mechanisms of the Transnistrian conflict, "Romanian Political Science Review", Vol. 6, No. 4.

Vadim Krasnoselsky (2019), Vadim Krasnoselsky nahoditsya v Gosudarstvennoj Dume Rossijskoj Federacii, Ministerstvo inostrannyh del Pridnestrovskoj Moldavskoj Respubliki, 25.09.2019, $\mathrm{http} / / / \mathrm{mfa}-\mathrm{pmr} . \mathrm{org} / \mathrm{ru} / \mathrm{ypy}(30.03 .2020)$.

Vardanean E. (2018), Transnistrian conflict: Analysis and policy recommendations, in: Frozen ground: Role of the OSCE in protracted conflicts. Recommendations for Slovak OSCE Chairmanship, (eds.) K. Báňaiová, S. Goda, Bratislava.

Vneshnyaya politika (2012), Vneshnyaya politika Pridnestrovskoj Moldavskoj Respubliki - Nina Shtanski vystupila s lekciej v Yalte, Ministerstvo inostrannyh del Pridnestrovskoj Moldavskoj Respubliki, 03.04.2012, http://mfa-pmr.org/ru/xDN (20.07.2020).

Vneshnyaya politika (2016), Vneshnyaya politika Pridnestrovya na sovremennom etape: novye tendencii i mekhanizmy realizacii, Ministerstvo inostrannyh del Pridnestrovskoj Moldavskoj Respubliki, 14.11.2016, http://mfa-pmr.org/ru/yPJ (09.02.2020).

Vneshnyaya torgovlya (2021), Vneshnyaya torgovlya-2020: itogi i faktory, "Pridnestrove", 05.02.2021, http://pridnestrovie-daily.net/archives/53167 (21.02.2021).

Volkova A. Z. (2009), Referendumy v kontekste istorii stanovleniya i razvitiya institutov demokratii v Pridnestrove (konec 1980-h-2000-e gg.), "Vestnik Sankt-Peterburgskogo universiteta", Ser. 2, Vyp. 1.

V Pridnestrove (2019), V Pridnestrove predstavlen "Rossijskij torgovyj proekt", "REGNUM", 17.07.2019, https://regnum.ru/news/economy/2667241.html (21.02.2021).

V Pridnestrove (2020a), V Pridnestrove nazvali vyvod rossijskih vojsk "iskusstvennoj problemoj", 02.12.2020, https://www.rbc.ru/rbcfreenews/5fc73f5e9a79476ad66848e8 (21.02.2020).

V Pridnestrove (2020b), V Pridnestrove postupila pomoshch ot Rossii: kto ee poluchit, "Ritm Evrazii", 12.01.2021, https://www.ritmeurasia.org/news--2021-01-12--v-pridnestrovepostupila-pomosch-ot-rossii-kto-ee-poluchit-52745 (21.02.2021).

Wolff S. (2012), The Transnistrian Issue: Moving Beyond the Status-Quo, Brussels.

\begin{abstract}
The article outlines cursory viewpoint on Transnistria as the focus of the Russian Federation policy. Russia pursues political interests in Transnistria connected with its geostrategic ambitions on the post-Soviet state. It is revealed that Moscow has a great impact on the life of Transnistria and cooperates with Tiraspol in political, military, social, cultural, and economic
\end{abstract}


spheres. It is discussed that Russian military presence in this de facto state helps not only to control Transnistria but also Moldova concerning its geopolitical choice. In the article Russia's activity concerning conflict resolution in Transnistria is shown. A special attention is paid to the Kozak Plan aiming at unification of Transnistria and Moldova, according to which too-extensive rights to Transnistria had to be given. Although this plan was not implemented, in fact now its idea is promoted gradually through convergence of Moldova and Transnistria. In the article it is stressed that russification of the region influences on the mood of the population concerning the future status of the region. Social and economic relations between Russia and Transnistria are researched. It is revealed that all three presidents of this de facto state had close ties with the Russian government and coordinated their politics with it. It is discussed that officially Russia supports territorial integrity of Moldova but at the same time it gives comprehensive support of Transnistria. Although it is not declared in the documents, now the Russian Federation favours status quo in Transnistria.

Keywords: Transnistria, Russia, de facto state, cooperation, international recognition

\section{OGÓLNY PUNKT WIDZENIA NA NADDNIESTRZE JAKO PRIORYTET POLITYKI FEDERACJI ROSYJSKIEJ}

\section{STRESZCZENIE}

Artykuł przedstawia rosyjski punk punkt widzenia na Naddniestrze, które jest w centrum uwagi polityki Federacji Rosyjskiej. Rosja realizuje polityczne interesy w Naddniestrzu związane z jej geostrategicznymi ambicjami na przestrzeni poradzieckiej. Okazuje się, że Moskwa ma ogromny wpływ na życie regionu i współpracuje z Tyraspolem na płaszczyźnie politycznej, militarnej, społecznej, kulturowej i gospodarczej. Mówi się, że rosyjska obecność wojskowa w tym de facto państwie pomaga nie tylko kontrolować Naddniestrze, ale także Mołdawię, jeżeli chodzi o jej wybór geopolityczny. W tym artykule pokazano aktywność Rosji w zakresie rozwiązywania konfliktów w Naddniestrzu. Szczególną uwagę zwraca się na plan Kozaka, mający na celu zjednoczenie Naddniestrza i Mołdawii, zgodnie z którym należało nadać Naddniestrzu zbyt rozległe prawa. Chociaż plan ten nie został zrealizowany, w rzeczywistości jego idea jest obecnie stopniowo promowana poprzez zbliżenie Mołdawii i Naddniestrza. W artykule podkreślono, że rusyfikacja regionu wpływa na nastroje ludności dotyczące przyszłego jego statusu. Zbadane są relacje społeczno-gospodarcze między Rosją a Naddniestrzem. Okazuje się, że wszyscy trzej prezydenci tego de facto państwa mieli bliskie powiązania z władzami rosyjskimi i koordynowali z nimi swoją politykę. Mówi się, że Rosja oficjalnie popiera integralność terytorialną Mołdawii, ale jednocześnie udziela kompleksowego wsparcia regionowi. Choć nie jest to deklarowane w dokumentach, obecnie Federacja Rosyjska faworyzuje status quo w regionie.

Słowa kluczowe: Naddniestrze, Rosja, państwo de facto, współpraca, uznanie międzynarodowe 